Fariba Nosrati

McMaster University, Hamilton, Ontario, Canada

Claudi Crippa

McMaster University, Hamilton, Ontario, Canada

\author{
Brian Detlor \\ McMaster University, Hamilton, Ontario, Canada
}

\title{
THE USE OF IBEACON PROXIMITY-BASED TECHNOLOGIES BY LIBRARIES TO FOSTER CITY CULTURAL HERITAGE (Paper)
}

\begin{abstract}
:
This paper describes a project led by two libraries concerning the use of iBeacon proximity-based technologies to promote city cultural heritage. Findings suggest iBeacons are viable tools for libraries to share city cultural heritage stories that yield improved perceptions of a city and greater appreciation of a city's cultural heritage.
\end{abstract}

\section{Résumé:}

Cet article décrit un projet mené par deux bibliothèques concernant l'utilisation des technologies basées sur la proximité d'iBeacon pour promouvoir le patrimoine culturel de la ville. Les constatations suggèrent que iBeacons sont des outils viables pour que les bibliothèques partagent des histoires de patrimoine culturel de la ville qui produisent une perception améliorée d'une ville et une plus grande appréciation du patrimoine culturel d'une ville.

\section{Introduction}

This paper investigates the use of iBeacon proximity-based technologies by libraries as an opportunity to foster city cultural heritage. Proximity-based technology systems, such as iBeacons, allow users to receive information automatically when they are close to a physical spot (Khan \& Light, 2012). Using Bluetooth Low Energy, iBeacons provide users with high-quality, time-sensitive information based on a user's close physical locale (iBeacon Insider, 2017). Information from an iBeacon is automatically pushed to a user's mobile phone or tablet when users are in close physical proximity. Retailers and museums are early adopters of iBeacons as a means of providing a more personal and interactive experience for clients (Mallik, 2014, 2015; Martin, 2016).

Specifically, this paper describes a case study investigation of an iBeacon project led by the Hamilton Public Library (HPL) and McMaster University Library (MUL) in Hamilton, Canada. The pilot was launched to test the use of iBeacons as a means of promoting citizen interest in Hamilton's cultural history. The pilot involved the setup of iBeacons that disseminated stories pertaining to Gore Park - a prominent park in the heart of downtown Hamilton. Posters advertising Gore Park were installed in both libraries to entice citizens to download and experience a custom-made Gore Park app on their smart phones and tablets. Stories, including historical pictures, were sourced from HPL's Local History and Archives department. Each poster installed in the libraries pertained to a collection of stories about a particular object located in Gore Park (e.g., a monument, a fountain, a statue). If users installed the app on their smart phone or tablet and enabled Bluetooth, then their mobile device would "wake up" when the users were physically close to one of the Gore Park posters (i.e., the app would automatically receive stories about the image on the poster). 
Two versions of the Gore Park app were created and installed. The first version was developed and tested in Mills Library at McMaster University. The second version was developed and installed in Central Branch at Hamilton Public Library. The second version made significant improvements in the usability/navigation of the app and the amount of information content (i.e., stories) available for viewing.

The high-level research question guiding this study is: How can iBeacons, a specific proximitybased technology, be used by libraries to provide information that raises interest and awareness about a city's cultural heritage?

\section{Conceptual Framework}

To set the boundaries of our investigation, a conceptual framework was constructed based on two theoretical models from the Information Systems literature: i) the Information Systems Success Model (Delone \& McLean, 2003, 1992; Petter et al., 2008) which identifies key components of information system success, namely information quality, systems quality, user satisfaction and net benefits; and ii) the Model of Effective Use of Information Systems (Burton-Jones \& Grange, 2013) which stresses the idea that maximum benefits from an information system can only be realized if the information system is used effectively. Importantly, Burton-Jones \& Grange's model identifies two types of benefits: primary $\left(1^{\text {st }}\right.$ order) benefits and secondary $\left(2^{\text {nd }}\right.$ order) benefits.

\section{Methodology}

The study comprised both qualitative and quantitative research methods (Venkatesh et al., 2013). The qualitative portion involved one-on-one interviews with 50 participants from the general public who used the iBeacon app to experience the Gore Park stories. These interviews were conducted "on-the-spot" - that is, immediately after the participants were finished using the iBeacon app in the library. Interview questions asked participants to reflect on their experience using the iBeacon app and the impact the iBeacon app had in terms of their perceptions of the city of Hamilton and its cultural heritage. The interviews were digitally recorded and transcribed. From there, interview transcripts were analysed using grounded theory data analysis techniques advocated by Strauss \& Corbin (Corbin \& Strauss, 2014; Myers, 2013) to identify categories and relationships between those categories. DeDoose text analysis software was used to help conduct this analysis.

The quantitative portion involved these same 50 participants completing a short paper-based survey immediately after the participants were finished using the iBeacon app in the library. The survey quantitatively polled user perceptions of the app's systems quality, information quality, as well as user satisfaction and net benefits. Likert-scaled questions polled user perceptions on a 7point scale. Survey data were loaded into SPSS. Factor analysis and hierarchical regression was conducted on this data set to verify and test out the relationships between the categories identified in the qualitative phase of the study.

The study's conceptual framework informed the design of both the interview and survey instruments, as well as the analysis of the data.

Participants comprised a diverse and representative sample. That is, a wide range of people volunteered to participate in this study. Participants varied in age (48\% were between the ages of 18 and 24; 42\% were between the ages of 25 and 85); gender (36\% were male; 64\% were female), and education (29\%, 55\% and $16 \%$ of participants indicated their highest level of education achieved was a "high school diploma"; "college diploma/undergraduate degree”, or "master's/doctoral” degree" respectively. Participant diversity was also exhibited across ethnic backgrounds and participants' familiarity with information technology (e.g., some participants were new to technology, while others were technology wizards). 


\section{Findings}

Data collection and analysis is complete. Findings indicate that iBeacons can play an important role in strengthening the connection between people and cultural/historical objects by providing relevant, timely and location-based information when needed.

The comments made by participants in their interviews were very positive. People loved the digital stories and the iBeacon app. Many of the participants wanted to see more stories. They thought the archival pictures were incredible and many asked when the stories would be available for everyone to see and experience. A good percentage of the participants took the time to read all the stories. Some participants were emotional reading the stories. All participants said they learned something new about Hamilton and that the app was very informative. Most participants were satisfied with the app's system quality (90\%). Some participants mentioned the app helped revive their own personal stories and memories of Hamilton. Overall, most mentioned that by experiencing the stories in the iBeacon app that they gained benefit (89\%).

Specifically, analysis of the interview and survey data showed that:

- Information quality and system quality are important to participants and both lead to heightened user satisfaction and net benefits.

- Participants experience a layered impact of benefits from using the iBeacon app. The primary $\left(1^{\text {st }}\right.$ order) benefit was digital storytelling impact. City cultural heritage stories captured people's attention, engaged their emotions, fostered personal connections, and refreshed personal memories about a city. The secondary $\left(2^{\text {nd }}\right.$ order $)$ benefit was impression management. That is, the $1^{\text {st }}$ order impact led to a secondary benefit of creating positive perceptions about a city and increasing people's personal appreciation and emotional attachment towards a city's cultural heritage.

- Individual differences, such as gender and age, are important and can affect user satisfaction and net benefits of using the iBeacon app. For example:

o Women were more satisfied with the iBeacon app and more affected by digital stories than men. Net benefits were higher for women compared to men.

o Middle-aged participants (35-54) were most satisfied with the iBeacon app experience. This demographic was highly impacted by digital stories and indicated the highest net benefits.

o Older adults $\left(55^{+}\right)$were most affected by digital stories. They were also very satisfied with the iBeacon app experience and indicated high net benefits.

o Younger participants (18-34) were the least satisfied with their iBeacon app experience and least affected by the digital stories. However, they indicated fairly high net benefits.

\section{Concluding Remarks}

This study is inspired by Bates et al.'s (2002) notion of the need for cultural institutions such as libraries to expand their multimedia support for visitors. In response, this paper discusses how proximity-based technologies can provide libraries with an opportunity to strengthen their connection with people and foster city cultural heritage.

Findings suggest iBeacons are viable tools for libraries to share city cultural heritage stories that lead to user satisfaction, net benefits and positively affect people on a personal level yielding improved perceptions of a city and greater appreciation of a city's cultural heritage.

Moreover, this paper investigates the information behaviors or ways in which people interact with information (Bates, 2010), specifically in terms of using an iBeacon app. Participant comments in 
this study were very positive; participants loved the digital stories and the iBeacon app. All participants mentioned that they learned something new and that the app was very informative. Findings indicate that individual differences are important and can affect information behavior regarding acceptance and use of an iBeacon app designed to promote city cultural heritage.

\section{Reference List:}

Bates, Marcia J. (2010) "Information Behavior." In Encyclopedia of Library and Information Sciences, 3rd Ed.; Bates, Marcia J.; Maack, Mary Niles, Eds. New York: CRC Press, vol. 3, pp. 2381-2391. Retrieved from http://pages.gseis.ucla.edu/faculty/bates/articles/informationbehavior.html. Last accessed on April 24, 2017.

Bates, M. J., Hulsy, C., \& Jost, G. (2002). Multimedia research support for visiting scholars in museums, libraries, and universities. Information Technology and Libraries, 21(2), 73.

Burton-Jones, A., \& Grange, C. (2012). From use to effective use: a representation theory perspective. Information Systems Research, 24(3), 632-658.

Corbin, J., \& Strauss, A. (2014). Basics of qualitative research: Techniques and procedures for developing grounded theory. Sage Publications. Los Angeles, USA.

Delone, W. H., \& McLean, E. R. (2003). The DeLone and McLean model of information systems success: a ten-year update. Journal of Management Information Systems, 19(4), 9-30.

DeLone, W. H., \& McLean, E. R. (1992). Information systems success: The quest for the dependent variable. Information Systems Research, 3(1), 60-95.

iBeacon Insider (2017). Retrieved from http://www.ibeacon.com. Last accessed on April 24, 2017.

Khan, A., \& Light, A. (2012). Marketing goes local: location-based marketing provides solutions to technology's disruption of product placement, promotion and pricing. Retrieved from http://www.pwc.com/ca/en/entertainment-media/publications/pwc-marketing-goes-local-201208-20-en.pdf. Last accessed on April 24, 2017.

Mallick N. (2014). How museums can use beacons to enhance visitor experiences. Retrieved from https://blog.beaconstac.com/2014/06/how-museums-can-use-beacons-to-enhance-visitor/. Last accessed April 24, 2017).

Mallick, (2015). 3 museums using beacons to enhance interactivity. Retrieved from https://blog.beaconstac.com/2015/02/3-museums-using-beacons-to-enhance-interactivity/. Last accessed April 24, 2017).

Martin, J.A. (2016). 6 things marketers need to know about iBeacons, CIO Magazine. Retrieved from http://www.cio.com/article/3037354/marketing/6-things-marketers-need-to-know-aboutbeacons.html. Last accessed April 24, 2017).

Myers, M. D. (2013). Qualitative research in business and management. Sage. London, UK.

Petter, S., DeLone, W., \& McLean, E. (2008). Measuring information systems success: Models, dimensions, measures, and interrelationships. European Journal of Information Systems, 17(3), 236-263.

Venkatesh, V., Brown, S. A., \& Bala, H. (2013). Bridging the qualitative-quantitative divide: Guidelines for conducting mixed methods research in information systems. MIS Quarterly, 37(1), 21-54. 